\title{
South African Black Learners' Perceptions of their Mathematics Teachers
}

\author{
Joseph R. Maimane \\ School of Teacher Education, Faculty of Humanities, Central University of Technology, Free State \\ Private Bag X20539, Bloemfontein 9300, South Africa \\ Email:jmaimane@cut.ac.za
}

\section{Doi:10.5901/mjss.2014.v5n27p522}

\section{Abstract}

Teachers are important in the development of their learners, and research shows that teachers are potent figures in the social behaviour modification of learners. Teachers are of the belief that because of their vast experience and seniority they can help learners learn. Learners on the other hand have different perceptions regarding their teachers as far as teaching of mathematics is concerned. Research has indicated that beliefs and conduct of teachers do have a bearing on the performance of the learners. This article attempts to argue that learners do have different perception of their mathematics teachers and that they are not only motivated by their mathematics teachers to choose mathematics as a subject.

Keywords: Perceptions, social behaviour modification, performance, conduct

\section{Introduction}

Mathematics is considered to be the core component of the school curriculum and at university level it is seen as a pivotal subject, both in its own right and also in its important connections in diverse fields such as the natural sciences, engineering, medicine, and the social sciences (Jones 2000:53; Githua 2013:174). Many parents and learners perceive Mathematics and Science as the most difficult subjects of the curriculum. Norton as quoted in The Star (2000:12) indicates that the research which was published by the British Broadcasting Corporation (BBC) shows that mathematics is the hardest subject for parents with $48 \%$ saying that they struggle with it and that four out of ten people can't understand it at all. Regarding the South African context, Ensor (1993/94:112) poses questions such as "How has success in mathematics come to be constructed under Apartheid? "How does this construction contribute to what it means to be Black, working class or female." The fear they experience is said to emanate from the lack of good teachers of Mathematics and Science in historically Black institutions in South Africa (Sookdin \& Thulare, 1999: 626) and that is why the present government, backed by the private sector, seeks to address this problem. Themba Maseko, a former director- general of the Gauteng Department of Education, as quoted by Sunday Times (2000:17) points out that many teachers are forced to teach these subjects even though they may not be suitably qualified: "The serious situation arises that when a school has no maths and science teacher, it takes the next available teacher, which adds to the poor quality of teaching in these fields." This statement was also echoed by most of the Black teachers who attended the conference of the Association for Mathematics Education of South Africa (AMESA) at the University of the Free State, on 3-7 July 2000.

Teachers play a major role in the development of their learners and they sometimes think that they can help learners learn. Ensor (1993/94:110) asserts that teachers in school share common expectations of good students and what constitutes 'success' in mathematics. This assumption is based on how much the learners are capable of learning because their perceptions during formative evaluation is dependent on the teacher's usefulness and meaningfulness of the teacher's action, procedures and practices (Githua 2013:175). Research on mathematics indicates that teachers express beliefs about the teaching and learning of mathematics which do not concur with what they do in their classroom practice or the expectations of learners about what constitutes mathematics. Masutha \& Ackermann (1999:243) aver that the teachers' actual behaviour is not that much of a factor but it is rather the learners' perceptions of such behaviour. Purkey \& Novak (1984:37) state that teachers' perceived behaviour significantly influences students' behaviour. In her research, Anthony (2000:5) observed that learners and lecturers regarded motivation as being a factor that is important for success. Hamachek (1985:256) asserts that teachers' expectations can be a powerful force in shaping students' behaviour and in influencing achievement outcomes. Macpherson (1983:7) mentions the fact that students accept the authority of the teachers and they are concerned with success in school subjects as defined and evaluated by teachers. 
The majority of tertiary institutions of higher education which catered for Black education during the era of Apartheid were characterised by lack of teaching- learning resources which could motivate the aspirant teachers. Education stimulation, academic motivation, human resources and sound infrastructure were very scarce commodities. According to Masutha \& Ackermann (1999:244) the inequality in the distribution of resources creates social, cultural and educational disadvantages for learners and the teacher is viewed as the significant other. This view caused learners to imbibe what their teachers taught them without questioning issues. With the advent of Curriculum 2005, the stereotype teaching methods and passive learning mode changed to a learner- centred approach where the learner is actively engaged in constructing his/her own knowledge and critical understanding of meaning (Department of Education (DOE) 1997:130-133) and (Wilkinson \& Strauss 1998:251).

\section{Theoretical Framework}

Vygotsky's zone of proximal development (ZPD) stands out as the main theoretical point of departure for this study because it serves as a guide that is expected to invoke a host of values and beliefs that are shared in a common paradigm with other scholars (Omirin and Falola, 2011). The underlying assumption behind the concept is that psychological development and instruction are socially ingrained. To understand these assumptions one need to analyse the surrounding community and its social relations. To be able to understand them a form of guidance is crucial because there are multitude of things that a person encounters during a process of development. To be mentally, emotionally, spiritually, aesthetically and socially developed the direction of development is guided by instruction in scientific concepts considered to be important by the curriculum planners and teachers. Vygotsky points out that the main characteristics of instruction are that it creates the zone of proximal development, stimulating a chain of inner developmental processes. Daniels (1996:172) quotes Vygotsky as stating that: "The child is able to copy series of actions which surpass his or her own capacities, but only within limits. By means of copying, the child is able to perform much better when together with and guided by adults than when left alone, and can do so with understanding and independently. The difference between the level of solved tasks that can be performed with adult guidance and help and the level of independently solved tasks is the zone of proximal development."

\section{Purpose of Research}

The main purpose of this study was to investigate learners' perceptions of their maths teachers in influencing them in choosing mathematics as a subject to be done.

\section{Research Method}

The study was conducted among the Grade11 and12 learners who attend the Ikhwezi Mangaung Project on Saturdays at Tsoseletso High School because they were found to be readily available. Ikhwezi Mangaung Project is the idea and creation of Ikhwezi Mangaung Community Trust - a non-governmental organisation. A sample of fifty learners was randomly selected from a population of a hundred learners who attend the project. The sample comprised fifteen girls and thirty-five boys. They were of the same age group, that is, 15years to 16years old. Five of them ( 3 boys and 2 girls) come from the neighbouring townships of Thaba Nchu and Botshabelo. The remaining, that is, 13 girls and 32 boys are the Bloemfontein children. Thirty-eight (76\%) participants are in Grade 11 and twelve (44\%) are in Grade 12. The twelve participants have been with BTP since 1999 while the thirty-eight are new recruits of the project. They are all Sotho (Tswana and South Sotho) speaking learners and their understanding and articulation of English is of a considerable standard. Their personal traits differ with the Grade 11s being mostly shy, fearful, and uncertain and showing lack of confidence. The Grade 12s on the other hand are assertive, confident, aware of their needs and interests. What is common about them is the willingness to share their experiences. The medium of instructions in their schools is English although mother-tongue is sometimes used in helping them understand some scientific concepts.

The study was done on four consecutive Saturdays because of the limited time of about ten minutes, which was allocated to the study by the project facilitator. During the first Saturday five learners from the non-participating group, who were selected randomly, were interviewed with the view of testing the tentative questions the researcher had in mind. Data was collected by means of a tape-recorder, coded and analysed. Results indicated that most of them had different perceptions of their mathematics teachers. The questions used in the pilot study were then modified and were then used in the conduct of the semi-structured interviews with questions based on the following areas: their reasons for taking mathematics as a subject; perceived teachers' attitudes towards mathematics; their perceptions of their 
mathematics teacher and the learners' self- concept.

The following are typical examples of questions which were used in each area mentioned:

Area 1: Who really encouraged you to do mathematics?

Area 2: What does your teacher think about mathematics?

Area 3: What is your opinion of your maths teacher?

Area 4: What do you think about yourself as a learner who is taking mathematics as a subject?

The purpose of the study was not to treat these areas as totally independent of each other, but to try to make meaning of what the learners said and how they reacted to some questions. They were encouraged to respond frankly about anything as confidentiality was assured.

The analysis in this study is qualitative and there is no attempt at quantification. An axil analysis of data helped in the clustering of responses. Some of the responses are quoted verbatim to illustrate the nature of the learners' perceptions.

\section{Comments Made by Learners}

The overall responses of the fifty learners who were interviewed showed a remarkably positive movement towards the enthusiasm generated by their mathematics teachers. The majority of them indicated that their mathematics teachers' behaviour has an impact on their interest in the subject.

\subsection{Area 1: Who really encouraged you to do maths?}

Learners had different comments about who really encouraged them to do mathematics and the effect it had on their academic performance, as the following comments indicate:

\footnotetext{
"Eee,... with me, my parents said I should take mathematics because people with mathematics get better jobs. So, I work hard so that I should be easily hired when old."

"My brother is doing mathematics at the technikon, so I want to be like him and go to the university or the technikon when I complete Grade 12."

"No one encouraged me, I took mathematics because I so that people are afraid of it...actually, I took part in maths competitions. That is why I like mathematics and I took it as one of the subjects."

"I think the person who encouraged me, as far as I am concerned, is my Grade 9 maths teacher. She was good and the way she taught maths, the whole class enjoyed it. I think that is the person."
}

It is clear that some learners took mathematics as a subject because of the encouragement from their parents, teachers, siblings, competitions and what mathematics can do for them in future. Their explanations occasionally penetrated deeper than the ordinary comments:

"As far as I am concerned, I thought it was necessary to have mathematics as a subject because it can help me to quickly count and help other people. I also thought that it will help in the building of our country....Mandela said we should learn."

"Mathematics, just like science, is life. I enjoy it. You see, Menneer, with maths you can go far. I took it because I want to enjoy life when I am old. I want to be rich, you see?"

The positive comments expressed by the learners signify the positive attitude they have about mathematics. This may be attributed to various factors such as socio-economic and their teachers' beliefs and their expectations from the learners, to name a few.

\subsection{Area 2: What does your teacher think about mathematics?}

"My teacher seems to love mathematics. He is always lively when he teaches it." 
"He says maths is life. Whenever he teaches, he throws his hands around, call us by our names in order to say something, I think, mmm...he is mad about maths."

"Mam, says that there is nothing we can do without mathematics. She says if we want to do medicine or engineering, we need to have a background of maths. She says that mathematics will help us in future. I think that she loves it."

Much has been written about teachers' efficacy and how it has impacted on the academic performance of the learners. The attitude of teachers towards the subjects they teach can be clearly described by their learners.

\subsection{Area 3: What is your opinion of your maths teacher?}

"My maths teacher is a person who wants us to understand and love mathematics. When you approach him with a mathematical problem, he is always willing to help. This is encouraging."

"If other teachers were like our maths teacher, I think all the learners would pass the examination with flying colours. He is dedicated to his work and he makes maths easy and practical."

"He loves the subject although he is too strict. If you are lazy, you will be in trouble with him."

Some learners indicated a different opinion about their mathematics teacher(s):

"My teacher seems not to know mathematics. When you ask him why some expressions do not follow rules, he will always say: 'They are born like that' and this is discouraging."

"Since I joined the BTP programme, I have noticed that he sometimes leaves out some sections of the work saying that they are for the higher grade learners."

"We wonder whether he is qualified to teach mathematics. You ask him questions; he will shout at you and tell you that you do not listen when he teaches. I really doubt him."

These and other similar comments clearly indicate that learners are not only concerned with the quality of lesson presentation by the teacher, but they also detect his/her weak side. The rapport between teachers and the learners can be affected if teachers are not conversant with their subject matter. Learners are not empty vessels that are sent to school. They think and participate in various programmes outside school which arm them with knowledge.

\subsection{Area 4: What do you think of yourself as a learner who took mathematics as a subject?}

"I think I am lucky to do maths because my teacher is a person who loves his work and he motivates us to do well. Since I started with it, I enjoy coming to school."

"I am happy. Eee!.... I think I am confident enough to tackle other subjects. You know, maths is regarded as a difficult subject but I love it. It keeps me busy and I am happy to have a teacher who really makes it interesting for us."

"I am interested in engineering. I feel confident that with the mathematical knowledge I gained from my teacher I will be able to achieve my wish. I do not regret doing mathematics."

Learners' confidence about their teachers seems to be high and they do not regret taking mathematics as a subject. They see their future as revolving around mathematics and feel assured that they will succeed in life because of it.

\section{Ethical Considerations}

In this study, the researcher complied with ethical issues of confidentiality, anonymity, privacy and respect of properties of others. The data gathered in this exercise was solely and strictly used for the purpose of this study (McMillan \& Schumacher, 2010 and Neuman, 2006). Permission to conduct this study was sought from the Department of Education. The informed consent was also sought attained from both the principal of the school and the educator who were fully informed about the research process and purpose of the study. 


\section{Discussion}

The majority of learners do have varying perceptions of their mathematics teachers. During the interview, the majority of them indicated that their teachers do have an impact on their approach to the subject.

In Areas 1 and 3 (Who really encouraged you to do maths and what is your opinion of your mathematics teacher) learners indicate different people who made them take mathematics because of the difference benefits they feel exit in taking it.

"I think the person who encouraged me, as far as I am concerned, is my Grade 9 maths teacher. She was good and the way she taught maths, the whole class enjoyed it. I think that is the person."

Family members also encouraged them. "Eee,... with me, my parents said I should take mathematics because people with mathematics get better jobs. So, I work had so that I should be easily hired when old."

Personal choice, which grew out of the need to be something in life when they are old, plays a part in doing mathematics. "I think the person who encouraged me, as far as I am concerned, is my Grade 9 maths teacher. She was good and the way she taught maths, the whole class enjoyed it. I think that is the person." This attitude is in concert with what Child (1993: 108) is saying about modelling, that behaviour is sometimes initiated in an observer by the cues given to the person from the model.

Some of the learners indicated that their former maths teachers contributed to their choice of maths as a subject because of the way they taught it. The majority of the participants responded that the way their teachers approach mathematics is motivating, encouraging, practical, and above all, the way they make it look easy, all the learners could pass the examination with flying colours. This is also highlighted by the results of the pilot group that their teachers are 'lively'. Child (1992: 108- 109) states that the distinctive styles of the teacher as a model of social behaviour, that is, his/ her aggressiveness, friendliness, aloofness cooperativeness, calmness, etc., will act as the initiators of novel behaviour changes in the child. Some of the respondents did indicate negative perceptions of their teacher. They indicated the negative manner in which their maths teachers respond to their questions when they sought clarity on some issues: "We wonder whether he is qualified to teach mathematics. You ask him questions, he will shout at you and tell you that you do not listen when he teaches. I really doubt him."

The negative approach by the teacher can have an impact on the achievement of the learner and it can also inculcate hatred for the subject if the teacher does not respect the learner especially if he/she is a low achiever. In the research conducted by Masutha \& Ackermann (1999:246) high achievers and low achievers pointed out that teachers treat them differently. This view concurs with the findings of Anthony (2000:11) regarding the distinguishing factors between successful and failing students, that is, the need to make the paper requirements clear.

The responses in Areas 2 and 4 (What does your teacher think about mathematics? and What do you think of yourself as a learner who took mathematics as a subject?) seem to indicate that learners are being motivated by the manner in which their mathematics teacher(s) think about the subject.

Hoyle (1969:59) maintains that the way a teacher performs his/ her classroom role is dependent upon the external factors such as the teaching situation itself, and the personality of the teacher. In these areas the subject presentation of teachers seems to elevate the spirit, academic achievement and self- concept of the learners by annihilating the fear that they have. Sookdin \& Thulare (1999: 628) state that the elimination of fear will enable learners to apply their talents in maths and science related fields. Teachers' expectations and efficacy, as revealed in literature, seem to be true for these areas and the study as a whole.

\section{Implications and Concluding Remarks}

Comments made by learners are clear interpretations of the dynamics that prevail in the classroom situation. Learners are sensitive to the manner of messages which are being communicated to them and the role of interpersonal relationships, as a whole. Their comments sought to engage the attention of the school with regard to their interest and the teaching styles of teachers. In order that teachers should leave an indelible mark on the love for the subject, they should create a conducive teaching- learning atmosphere characterised by trust. Once a cordial relationship is created between a teacher and learners, effective learning will take place and learners' performance in mathematics will change and they will develop positive perceptions of teachers. Curriculum 2005 makes it clear that learners should be at the centre of all pedagogical activities and that the teacher's role should be that of a facilitator. The position of being mere 
facilitators is a foreign phenomenon to South African teachers and they view it as being problematic. Wilkinson \& Strauss (1998:255) stress that in-service training is the best option to help teachers cope with the situation. They call on the government or the provincial government and the non-governmental organisations to help teachers.

Teachers' attitudes to mathematics, as described by some of the learners, can cause damaging ramifications which could make learners hate and fear mathematics. Teachers' behaviour and expectations of students should not be completely based on their beliefs and experiences as former learners of mathematics. What the teachers need to do is to thoroughly prepare the learning content before presenting it to the class and they should not rebuke learners. Claxton (1990:10) says what you do as a teacher will influence the way your pupils decide to learn in your lessons, and the sort of learning that therefore results.

The implication of the comments made by the learners calls for teachers to enable the socially useful type of learning to occur by interacting in a sound teacher- learner relationship characterised by respect for the dignity of the individual. Mathematics teachers should refrain from acting as barriers to communication and motivation by negatively responding to learners' questions. They should be perceived as source of inspiration by their learners.

Mathematics teachers should attempt to eradicate the misconceptions that mathematics is a difficult subject by contextualizing it so that the learners should not fear it but regard it as being important in their daily lives.

Mathematics teachers should bear in mind that learners need to be encouraged to ask questions and that they should be helped to develop a self-image and self-confidence by the positive responses learners receive from them. They should encourage learners to brainstorm some mathematical problems and discuss programmes for the better understanding of mathematics with them.

Learners need to be encouraged to participate in various competitions where mathematics, science and technology are involved, so that the misconceptions that mathematics is difficult should be turned into a motivational factor.

Teachers should consciously use learners' curiosity as a valuable learning resource by encouraging them to share ideas, experiences and strategies to tackle mathematical problems they encounter.

Learners' curiosity should be nurtured in such a way that they are able to think critically and endeavour to search for more knowledge associated with mathematical questions. According to Maimane (2006: 244) the teaching and learning of mathematics goes beyond classroom activity and should be perceived as a process that transcends the limits of the school.

In conclusion, it is clear from this study that maths teachers' behaviour has a great influence in demystifying the misconception that mathematics is a difficult subject. They should bear in mind that their attitude towards the subject, learners and the school as a whole can have adverse repercussions on how learners perceive them and their academic achievement.

Teachers should view learners as being able, valuable and responsible (Purkey \& Novak 1984:37) so that they should feel inspired by the subject and the teachers themselves. A prevailing conducive atmosphere will help learners acquire "universalistic values", that is parity of age that enables teachers to treat learners as members of a category by assigning them similar tasks, privileges and obligations (Macpherson 1983:7).

Placing the study in context, according to the outcomes based education approach; teachers are to be perceived by learners as a major source of support and as facilitators of learning and development, in contrast to the traditional approach which regards teachers as instructors (Masutha \& Ackermann (1999:246).

Finally, this study clearly points out that teachers or maths teachers' behaviour does play an important role in developing the love and interest of the subject on learners. Their positive approach to the subject and the actions they consciously or unconsciously express impacts on their relationship and learners' academic performance. It is therefore necessary that more maths teachers should be skilled so that they should be positively perceived by their learners.

\section{Recommendations}

The training of teachers should be characterised by vision, efficiency, accountability and excellence on the part of the government and all stakeholders. The government should arrange workshops that would help resource and empower mathematics teachers. Non-governmental organizations should also be invited to the task of resource production, auditing for quality assurance and control, and the overall supervision of all teachers who are involved in mathematics, science and technology. Teachers should accommodate the all learners and strive to empower them so that they could be passionate with mathematics. 


\section{References}

Anthony, G. (2000). Factors influencing First-Year Students' Success in Mathematics. International Journal of Mathematical Education in Science and Technology, 31(1): 3- 14.

Claxton, G. (1990). Teaching to Learn - a Direction for Education. London: Cassell.

Child, D. (1993). Psychology and the Teacher: $5^{\text {th }}$ Edition. London: Cassell.

Department of Education (DoE), (1997). Curriculum 2005. Specific Outcomes, Assessment Criteria, Range Statements. Grades 1-9. Discussion Document. Pretoria: Department of Education. April 1997.

Ensor, P. (1993/94). Boundaries at the Centre-Differentiating Pupils in Mathematics Classrooms. Perspective in Education, 15(1):104114.

Githua, B. N. (2013). Secondary school Students' Perceptions of Mathematics Formative Evaluation and the Perceptions' Relationship to their Motivation and Rift Valley Provinces, Kenya. Asian Journal of Social Sciences and Humanities, 2(1):174- 183.

Hamachek, D. E. (1985). Psychology in Teaching, Learning, and Growth: 3rd Edition. Boston: Allyn \& Bacon.

Hoyle, E. (1969). The Role of the Teacher, London: Routledge \& Kegan Paul.

Jones, K. 2000. The Student Experience of Mathematical Proof at University Level. International Journal of Mathematical Education in Science and Technology, 31(1):53- 60.

Macpherson, J. (1983). The Feral Classroom. London: Routledge \&Kegan Paul.

Maimane, J. (2006). Motivating Primary-school Learners in Mathematics Classrooms. Acta Academica, 38(2): 243-261

Mcmillan, J. H. and Schumacher, S. (2010). Research in Education: A Conceptual Introduction (7th edition.). Routledge: Longman.

Masutha, M. R. and Ackermann, C. J. (1999). Secondary School Students' Perceptions of their Teachers. South African Journal of Education, 19(3): 243- 248.

Omirin, M. S. and Falola, E.O. (2011). Educational research Theoretical and Conceptual Frameworks. Global Journal of Educational Research, $x(x): 009-012$

Purkey, W. W and Novak, J. (1984). Inviting School Success: a Self-Concept Approach to Teaching and Learning: $2^{\text {nd }}$ Edition. California: Wadsworth Publishing Company.

Sookdin, U. and Thulare, S. M. (1999). The Impact that the Bloemfontein Technology Project has on the Learner's Academic Performance and their Choice of Career in the Field of Engineering. Proceedings of the International Organization For Science and Technology Education. Durban: 26 June- 2 July 1999.

Sunday Times, 26 March 2000: 17. Maths And Science Not Up To Scratch.

The Star, 22 May 2000: 12. Parents are struggling with Children's Homework.

Wilkinson, A.C. and Strauss, J. P (1998). The Applicability of an Investigative Technology-Enhanced Approach to the Natural Sciences in Secondary Schools in the Free State. South African Journal of Education, 18(4):251-258. 